\title{
PENDIDIKAN DAN REALITAS SOSIAL (Analisis Struktur Konflik)
}

\author{
Muh. Zakaria*
}

\begin{abstract}
Abstrak: Tulisan ini membahas tentang realitas pendidikan ditengah sosial masyarakat dengan memfokuskan pada dualisme pendidikan, dimana yang menjadi masalah utama adalah dilihat dai segi kebijakan dan sistem pendidikan dibawah payung Kemendikbud dan Kemenag. Terlihat jelas perkembangan pendidikan di kementerian tesebut sangat jauh berbeda, sehingga lulusannya di persiapkan dengan orientasi yang berbeda pula. Misalkan saja dalam hal kurikulum mata pelajaran umum dan agama, keduanya memiliki porsi masing-masing (baca lembaga pendidikan umum dan lembaga pendidikan agama) misalkan pendidikan umum berorientasi sebagai pemenuhan kerja dan penguasaan teknologi untuk menghasilkan uang, sedangkan pendidikan agama berorientasi pada pembentuk akhlak, moral. Dalam realitas sosial tulisan ini juga mencoba memetakan dampak terhadap dualisme pendidikan tesebut, diantaranya pendidikan terkesan dipaksaakan baik dari segi pengembangan kurikulum, pendidikan semakin mahal, pemerosotan terhadap nilai-nilai agama, budaya dan sosial. sehingga pendidikan yang dicita-citakan sebagai agen of change hanya sebagai simbol dan slogan saja.
\end{abstract}

Kata Kunci: Pendidikan, Realitas Sosial, Stuktur, Konflik

$\mathrm{P}$

ada masa penjajahan sesuai dengan misi kolonialisme, pendidikan Islam begitu dianak tirikan, bahkan dikatakan sebagai lembaga pendidikan liar yang harus di hancurkan, hingga pembuatan peraturan untuk membatasi dan mematikan pendidikan islam. Menyelami sejarah pendidikan tersebut,

* Penulis adalah dosen PAI di Fakultas Tarbiyah Institut Agama Islam Hamzanwadi NW Pancor Lombok Timur. Email: muhammadzakaria00@gmail.com 
pendidikan sekarang memberikan gambaran pendidikan masa lampau akan terulang kembali dengan penguasa dan peraturan yang berbeda, kemerdekaan bangsa dan tanah air indonesia diraih dengan perjuangan darah, namun perhatian pemerintah terhadap pendidikan masih jauh dari standar. Khusussnya pendidikan Islam masih mengalami hidup mati (bainal hayat wal mamat) dalam menghadapai arus globalisasi, hanya sebagian yang masih eksis dan bertahan sebagai wakil pendidikan Islam lainnya, namun demikian tuntutan masyrakat pada lembaga pendidikan Islam semakin tinggi dan tentunya perubahan itu menuju yang lebih baik. Pemegang kebijakan pendidikan seakan-akan tidak mau tahu akan realitas tersebut.

Sama halnya dengan sistem pendidikan nasional diorientasikan pada kepentingan pemerintah dan bukan untuk kepentingan anak didik, pasar dan pengguna jasa pendidikan atau masyarakat. Alasannya, strategi pendidikan nasional adalah untuk membekali generasi muda agar mampu membawa bangsa dan negara cepat sejajar dengan bangsa lain yang lebih maju. Namun kendati demikian dalam implikasi perkembangannya tidak sesuai dengan apa yang dicita-citakan. Keahlian dan penguasaan IPTEK yang diperoleh setelah menamatkan studinya berada dalam posisi dimiliki secara individual dan siap dijual melaui kontrak kerja demi uang, bukannya menjadikan diri sebagai ilmuan yang peduli dengan nilai-nilai kemanusiaan, bangsa dan negara. Uang dan kekayaan materi benar-benar menjadi kekuatan, kekuasaan, dan alat kontrol kehidupan yang megantaarkan individu yang bersangkutan ketempat lebih tinggi, menyenangkan, aman, dan terhormat (Rembangy 2010, 173).

Berdasarkan apa yang menjadi problem di atas, secara kualitas baik kuantitas lembaga pendidikan dan lulusan yang dihasilkannya masih jauh dari apa yang dirancang dalam tujuan pendidikan, beralasan kemudian ketika seorang yang ahli dalam suatu bidang tertentu, dimana lebih memilih kontak kerja dengan imbalan (dibayar) lebih besaar, karena sebagaimana kita ketahui kemiskinan 
dan kesejahteraan ilmuan di indonesia kurang bahkan tidak diperhatikan sama sekali.

Pengaplikasian pendidikan haruslah melakukan pembaharuan dan inovasi, jika tidak akan tertindas dengan arus globalisai. Sebagaimana pemikiran soekarno menyumbangkan ide terhadap pemikiran pendidikan islam, mengatakan bahwa Islam is progress adalah kata kunci yang menjadi latar belakang sekaligus kekuatan pemikiran kamajuan pendidikan Islam diartika sebagai pembaharu, sebab tanpa pembaharuan kemajuan hanyalah isapan jempol belaka. Lebih lanjut menyerukan umat Islam harus melepaskan diri dari belenggu taklid yang membayangi umat Islam dari kejayaan Islam masa lampau (Islam Glory), keluar dari taklid dan melakukan tajdid, keberanian melakukan pembaharuan merupakan langkah menuju kemajuan dan mengejar ketertinggalan pendidikan islam, dimana fiqih bukanlah hasil final melainkan kreasi ulama yang harus dipertanyakan dan disesuaikan dengan zamannya. Kenangan kejayaan Islam masa lampau membuat Islam sekarang mengalami kejumudan terutama pada lembaga pendidikan Islam di berbagai kalangan di inodonesia (Kurniawan 2009, 183). Selain hal demikian masalah yang tak kalah penting yang berkaitan dengan kerangka ideologi dan profesionalisme pelaku pelaksanaan pendidikan disebagian besar masih terpaku pada model konvensional, menekankan pada metode ceramah dan cenderung doktrinatif (Arif 2008, 210).

Hal senada yang dikatakan Giroux bahwa suasana kelam pendidikan diperparah dengan sikap ketidak berdayaan menghadapi perubahan dan manjauhkan wacana dari upaya-upaya perubahan. Pendidikan di ibaratkan dalam kotak besar yang mengurung praksis pendidikan beserta semua orang yang terlibat didalamnya kemudian kotak tersebut dikendalikan oleh pihak tertentu, akibatnya menggoyahkan para pelaku pendidikan. Giroux menolak hakikat sekolah sebagai satu wahana sebagai perjuangan kultural dan politik yang membatasinya sebagai instrumen kesempatan meningkatkan diri. Harapannya para pelaku pendidikan mampu menembus unsurunsur subordinatif, maka agenda pertama adalah menyadarkan para 
pelaku pendidik tentang tetapan visioner bahwa pendidikan adalah pelibatan politik (Awignyo 2008, 16). Sejauh ini kita melihat bahwa pendidian akan selalu berjalan dengan perubahan sosial, tatanann nilai, moral perkembangan individu, tingkat kesejahteraan ekonomi dan struktur masyarakat. Namun yang terpenting adalah tatanan sosial dimana didalam dinamikanya menyagkut teknoekonomi. Temuan-temuan teknologi yang mendorong kamajuan dan pencapaian di bidang ekonomi yang menjadi agen perubahan dalam dunia pendidikan dan sosial-masyarakat.

Ketika pendidikan menentukan dan mengendalikan perubahan, bukan harus potong kompas dan langsung menentukan kemana pendidikan mesti mengarah melainkan merepleksikan untuk menimbang, mengamati dengan melihat realitas kekinian, jika tidak maka akan tercipta sistem pendidikan kapitalis, seperti mahalnya biaya pendidikan, terjadinya dualisme kebijakan pemerintah, kurikulum yang tak tentu arah. Inilah kenyataanya yakni pendidikan harus berlangsung di dalam arus perubahan yang begitu kuat, yang berbagai tuntutannya memaksa pendidikan keluar dari visi dan nilai kewibawaan sejatinya. Kemajuan teknoekonomi merupakan bukti prestasi manusisa, tapi kemajuan itu menjadi penyakit bagi aspek sosial dan kebudayaan manusia, dimana merubah cara pandang manusia secara radikal. Usaha mencari paradigma ditengah arus perubahan penting dimulai dengan prinsipal dimulai dari paradigma lain diluar paradigma kapitalis, dimaksudkan tidak melawan dan menghapus kapitalisme, melainkan mengimbangi dan memberi warna dalam kapitalisme. Dengan kata lain keluar dari dikotomis untung rugi finansial dalam penyelenggaraan pendidikan (Awignyo 2008, 22-24).

Semangat misi orientasi dan manajemen pendidikan di atur dan dikendalikan oleh Teknoekonomi dan dibaliknya sistem kekuasaan kapitalisme yang menjadi kekuatan terbesar. Berangkat dari hal tersebut Pada dasarnya pendidikan diharapkan mampu menjawab persoalan masyarakat dan kesenjangan sosial, dalam sistem pendidikan memiliki tujuan agar masyarakat melek terhadap perkembangan zaman dan kemajuan teknologi. Tugas pendidikan 
menawarkan kemandirian kecerdasan dalam kehidupan berbangsa dan bernegara.

Mengacu pada permasalahan pendidikan di atas dinamika dunia pendidikan ditengah-tengah realitas masyarakat maka penulis mencoba menganalisis dengan berbagai pandangan dengan membagi kebebrapa pokok pembahasan, diantaranya; propesionalisme pelaku pendidikan, dualisme pendidikan (Desentralisasi dan sentralisasi pendidikan), kemudian pendidikan dan realitas sosial, dan sebagai sub terahir kesimpulan.

\section{Dualisme Pendidikan}

Yang dimaksudkan dengan dualisme dalam tulisan ini adalah sistem dan kebijakan pendidikan, baik kurikulum yang dikembangkan dilingkungan pendidikan umum dan pendidikan agama. Yang pada akhirnya melahirkan dualisme kebijakan yakni sentralisasi dan desentralisasi, dengan sistem dualisme pendidikan permasalahan pendidikan semakin hari makin membengkak, berbagai solusi dan perubahan dilakukan dengan mengatas namakan kepentingan masyarakat. Dengan demikian pendidikan didudukkan dititik sentral suatu masyarakat dimungkinkan karena persepsi masyaraka kontemporer, sekolah semakin tinggi nilainya. Secara historis pendidikan dimasa lalu berada dipinggiran, tidak dianggap begitu penting, namun makin hari dibutuhkan dan begitu penting dan berperan dalam memberikan solusi terhadap masyarakat (Isjoni 2010, 67). Pangkal dari perubahan tersebut adalah terjadinya revolusi teknologi yang membawa perubahan dalam beberapa aspek kehidupan: sosial, ekonomi, dan budaya, baik aspek fisik dan nilai yang terkandung didalamnya.

Perdebatan dikotomi pendidikan berjalan sekian lama berlangsung dan itu terkait dengan kepentingan politik, dokotomi pendidikan sampai saat ini tak kunjung usai. Itu terlihat disaat sistem kurikulum pendidikan nasional terus mengalami perubahan, bahwa setiap perubahan desain kurikulum terjadi, maka setiap itu juga terdapat kepentingan politik penguasa didalamnya. Dikotomi tersebut membelah wajah pendidikan nasional menjadi dua 
pendidikan umum dengan karakter khas dibawah naungan departemen Pendidikan Nasional, dan yang kedua pendidikan agama sebagaimana yang kita ketahuai dibawah naungan Depag. Dua wajah pendidikan inilah menjadi warna pendidikan indonesia dari sejak kolonial hingga saat ini (Mu'arif 2008, 28).

Kebijakan pendidikan adalah kebijakan publik di bidang pendidikan, sebagaimana yang dikatakan mark Olsen, bahwa kebijakan pendidikan merupakan kunci bagi keunggulan, bahkan eksitensi sebagai negara bangsa dalam persaingan global, sehingga kebijakan pendidikan perlu mendapatkan proritas utama dalam era globalisasi, dengan argumen globalisasi membawa demokrasi, kemudian demokrasi yang memberikan hasil yang didukung oleh pendidikan (Tilaar dan Nugroho 2009, 267). Jika demikian para elit politik pendidikan yang memegang kekuasaan akan mengatur pendidikan ini sesuai dengan kepentingan politiknya semata. Ini terlihat sebagaimana yang dikatakan Romo Magnum, negara tidak menyusun suatu sistem pendidikan yang pada hakikatnya telah membelenggu perkembangan peserta didik, sistem pendidikan yang kaku, kurikulum, para pendidik, dan berbagai peraturan negara pada hakikatnya tidak memberikan kesempatan pada perkembangan pribadi yang seluas-luasnnya bagi peserta didik terlebih bagi masyarakat yang tidak mampu (miskin). Dalam uraian tersebut jelas betapa pendidikan sangat erat kaitannya dengan struktur kekuasaan di dalam masyarakat. Kekuasaan yang merampas hak-hak asasi manusia yang pada akhirnya berakibat fatal terhadap perkembangan manusia (Tilaar dan Nugroho 2009, 9293).

Kemudian kendala yang dihadapai dengan dua kebijakan tersebut yakni, bermunculannya lembaga akademis untuk menilai mutu pendidikan, baik program studi dan lembaganya, dan akan menjadi prioritas oleh masyarakat dan para industrialis akan datang membanjirinya dengan menawarkan berbagai kerja bisnis dengan keuntungan yang menggiurkan, sehingga pendidikan menjadi mahal saat ini (Mastuhu 2004, 137). Sebagaimana yang dikatan Marx bahwa, kualitas telah terbalik karena kapitalisme dan uang telah 
memanipulasi kualitas; bahkan kualitas oleh uang dalam kapitalisme, dapat disulap menjadi sebaliknya buruk jadi jelek, jelek jadi buruk, bermutu jadi hina, serius jadi tidak berguna dan tidak dihargai, dan kepalsuan jadi pujaan. Karenanya kekuasaan uang membalikkan semua kualitas manusia dan alam, membuat yang tidak sesuai menjadi persaudaraan sehingga kekuasaan suci uang berada dalam karakternya sebagai kehidupan spesies yang teralienasi (Soyomukti 2008, 106).

Mengenai hal di atas respon masyarakat akan dibutuhkan atas dualisme kebijakan pendidikan tersebut, dimana respon tersebut bisa berupa dukungan dan perlawanan, karena setiap kebijakan yang dibuat pemerintah berhubungan erat dengan masyaraka, dengan logika, jika kebijakan itu dikeluarkan dengan sepihak oleh pemerintah tanpa melihat realitas sosial masyarakat, mau atau tidak harus ditrima, namun dalam pelaksanaannya akan terjadi penyimpangan (Assegaf 2005, 207). Sebagaimana yang dikatakan Arcaro, menyebutkan bahwa dasar misi peningkatan kualitas sebuah sekolah adalah mengembangkan program dan layanan yang menenuhi kebutuhan pengguna, seperti masyarakat. Kemudian harus diawali dengan kesepakatan bersama dari para aktor di sekolah dan komunitas sekolah tersebut (Dwiningrum 2011, 9-91). Perubahan dalam sistem pendidikan seringkali dilakukan, namun untuk apa perubahan tersebut?, sampai tingkat mana perubahan itu dilakukan?. Dimana realitas sosial belum bisa mengaktualisasikan pendidikan di tengah perubahan sosial mereka (Assegaf 2005, 174177).

Dalam sistem desentralisasi dipokuskan pada penataan pusat dan daerah. Daerah perlu memiliki peluang mengembangkan pendidikan sesuai dengan kebutuhan dan potensi di daerah. Sedangkan pusat mengurus hal-hal strategis pada tatanan Nasional, yakni pengembangan monitoring, pembakuan mutu, moral dan karakter bangsa, dan pemberian kesempatan pendidikan pada masyarakat yang kurang beruntung, namun pelaksanaannya sangat tergantung dimasing-masing daerah. Modal uang, tanah, teknologi dan sumberdaya manusia perlu dalam proses penyelenggaraan 
pendidikan. Tidak kalah pentingnya adalah modal sosial (sosial capital). Dalam bentuk insprastruktur yang kuat. Hal ini yang membuat belenggu dalam pelaksnaan otonomi, dimana dalam pengelolaan pendidikan sering dilakukan dengan sistem sekolah berbasis masyarakat sehingga penyempitan dengan bagian pengelolaan ruang bagi masyarakat, seperti halnya dengan mementingkan daerahnya sehingga persaingan tidak sehatpun terjadi, yang pada ahirnya otonomi kehilangan tujuan (Jalam 2001, 99-101).

Kebijakan pendidikan nasional seringkali mengabaikan kepentingan rakyat jelata penyelewengan banyak terjadi oleh para penguasa dan berakibat patal terhadap rakyat (masyarakat). Karena setiap kebijakan pasti akan berpengaruh terhadap kehidupan rakyat, yang pada akhirnya rakyat menjadi tumbal dan penindasan yang dilakukan secara sistematis melalui jalur pendidikan nasional (Mu'arif 2008, 7). Dengan demikian mati bekunya kreativitas bangsa dan masyarakat terjadi bila dunia kreatif pikiran dikendalikan, dikuasai dan dipasung oleh sentralisasi kekuasaan dan monopoli kebenaran (Santoso, dkk. 2010, 19). Berdasrkan hal tersebut jelas terjadi dalam sistem pendidikan kita saat ini dimana desentralisasi dan sentralisasi pendidikan menjadi patikan dalam mengembangkan kreatifitas masyarakat dalam pendidikannya, dikatakan benar bila kebenaran itu datang dari dualisme tersebut, artinya penentuan keberhasilan dan paradigma pendidikan kita masih berpayung terhadap dualisme pendidikan.

Sebagaiman yang dikemukakan Paulo Freire bahwa pendidikan ditujukan untuk humanisasi diri dan sesama, melalui tindakan sadar untuk merubah dunia. Bagi Frerie, pendidikan haruslah berorientasi pada pengenalan realitas diri manusia dan dirinnya sendiri, dimana pengenalan itu harus bersifa subyektif dan obyektif (Santoso, dkk. 2010, 130). Dalam konteks pendidikan keindonesiaan dengan menyimak realitas kultural ini masih tampak dalam ruang-ruang kelas dan kuliah lebih pada pentransperan ilmu pengetahuan ketimbang pendidik dijadikan teman. 
Lebih lanjut Freire mengatakan dengan mengajukan pendidikan pembebasan atau dikenal dengan istilah problem posting education, yang didasarkan saling keterhubungan demokratis antara guru dan murid (patnership) terdapat interaksi yang saling menguntungkan, artinya demokratisasi isi dan metode pembelajaran memacu penelitian, kreatifitas dan kekritisan yang mendorong munculnya kesadaran. Ini merupakan pendidikan yang dimulai dengan realitas eksitensial kehidupan sesama (Santoso, dkk. 2010, 142).

\section{Pendidikan dan Realitas Sosial}

Berbicara pendidikan menyangkut pendidik, peserta didik, materi, pemerintah, masyarakat beserta perubahan di dalamnya, jelasnya berbicara pendidikan akan menyangkut perubahan sosial, dari waktu kewaktu menunjukkan betapa pentingnya pendidikan di negeri ini. Hubungan diantara keduanya (pendidikan dan masyarakat) merupakan starting point merumuskan hubungan pendidikan dengan realitas sosial bagian penentu dalam menentukan arah dan tujuan pendidikan dimana tujuan tersebut: Pertama, pendidikan sebagai pewaris budaya; Kedua, pendidikan sebagai pengembangan individu (llyas 2009, 5). Dengan merujuk kepada ketentuan perundangan Negara Indonesia (PP No. 19 Tahun 2005 Tentang Standar Pendidikan Nasional), dinyatakan bahwa Kualitas Pendidikan Nasional dapat diwujudkan apabila adanya hubungan antara delapan elemen yang terdapat dalam standar minimal. Delapan standar tersebut adalah standar isi, standar proses, standar kompetensi lulusan, standar pendidikan dan tenaga kependidikan, standar sarana dan prasarana, standar pengelolaan, standar pembiayaan, dan standar penilaian pendidikan dapat terpenuhi (Asmani 2011, 113).

Perubahan sosial budaya merupakan proses yang lebih bersifat alami daripada hukum (politik, ekonomi) hukum diciptakan oleh manusia dengan teknologis yang sangat kuat, walaupun secara langsung atau tidak hukum mempengaruhi kehidupan sosial budaya begitu sebaliknya istilah tersebut dinamakan "a peculear form of social life" dengan berkarakterkan bangsa itu sendiri (Rahardjo 
2009, 191). Tuntutan masyarakat yang semakin besar terhadap pendidikan serta kemajuan ilmu pengetahuan dan teknologi, membuat pendidikan tidak mungkin lagi dikelola oleh hanya dengan melalui pola tradisional, di samping cara ini tidak sesuai lagi dengan kebutuhan dan tuntutan masyarakat. Revolusi ilmu teknologi dan ilmu pengetahuan, perubahan masyarakat, pemahaman cara belajar anak, kemajuan media komunikasi, dan lain sebagainya memberi arti tersendiri bagi kegiatan pendidikan dan ini pulalah yang membuat kebijaksanaan untuk memanfaatkan media teknologi dan pendekatan teknologis dalam pengelolaan pendidikan sebagai bagian dari kebudayaan merupakan sarana penerus nilai-nilai, gagasan-gagasan, sehingga setiap orang mampu berperan serta dalam transformasi nilai demi kemajuan bangsa dan negara. Ini berarti bahwa pendidikan adalah wadah untuk mentransformasikan ilmu pengetahuan dan teknologi demi kepentingan hidup manusia (Miarso 2004, 51).

Semakin berkembangnya zaman, manusia dituntut untuk lebih baik dalam segala hal. Munculnya teknologi yang pesat saat ini membuat revolusi yang besar terhadap dunia. Semua pekerjaan terasa mudah dan murah (Abraha 2004, 110). Demikian pula dalam pendidikan yang berkaitan dengan proses pembelajaran di sekolah. Beberapa variasi metode yang digunakan untuk mengajarkan ilmu kepada anak didik yang semakin maju dan canggih. Hal ini berbeda sekali dengan keadaan beberapa puluh tahun yang lalu, di mana sistem belajar masih sangat sederhana dan tidak banyak menggunakan media teknologi (Mulkhan, dkk. 1998, 5). Tumbuhnya kesadaran terhadap pentingnya pengembangan media pembelajaran di masa yang akan datang harus dapat direalisasikan dalam praktik. Banyak usaha yang dapat dikerjakan. Di samping memahami penggunaannya, para guru pun patut berupaya untuk mengembangkan ketrampilan membuat sendiri media yang menarik, murah dan efesien, dengan tidak menolak kemungkinan pemanfaatan alat modern yang sesuai dengan tuntutan perkembangan ilmu pengetahuan dan teknologi. 
Oleh karena itu guru mempunyai tanggungjawab dan tugas yang menantang agar dapat mengintegrasikan penggunaan teknologi tersebut dalam proses pengajaran dan pembelajaran di dalam kelas. Dengan adanya teknologi multimedia dan komputer di sekolah guru bukan hanya merasakan perubahan dalam peranannya, tetapi ia juga belajar bagaimana caranya untuk mengajar menggunakan alat-alat teknologi baru, pendekatan-pendekatan baru dan kemahiran baru (Mulkhan, dkk. 1998, 22). Karena dengan penggunaan multimedia dan komputer dalam proses belajar mengajar khususnya PBM Pendidikan agama Islam, dapat menciptakan proses pembelajaran yang interaktif, iaitu adanya hubungan timbal balik antara guru dan peserta didik dan juga antara sesama peserta didik. Proses pembelajaran interaktif yang dijalankan hendaknya dapat mendorong semangat peserta didik untuk belajar dan munculnya inspirasi pada peserta didik untuk memunculkan ide baru, mengembangkan inisiatif dan kreativitas.

Namun pada hakikatnya, kemantapan dan keberkesanan proses belajar mengajar dengan menggunakan teknologi bergantung kepada keupayaan dan kemahiran guru untuk mengaplikasikannya sesuai dengan objektif pembelajaran (Sanaky 2009, 9). Pelbagai perubahan yang sering terjadi dalam dunia pendidikan dewasa ini, menuntut para pendidik khususnya guru agar peka dan bersedia untuk mengharungi tantangan dan rintangan, agar mereka tidak ketinggalan dalam menempuh arus pembangunan dan perkembangan teknologi komputer dan multimedia ini. Penggunaan komputer dan multimedia dalam proses belajar mengajar merupakan satu alternatif kepada kaedah tradisional, ia juga sebagai bahan bantu mengajar sehingga dapat menarik minat.

Meskipun teknologi informasi dan komunikasi (TIK) mempunyai peranan yang sangat penting dalam pengajaran dan pembelajaran di sekolah. Namun pada hakikatnya ia tidak dapat menggantikan posisi guru ataupun mengambil alih peranan sekolah (Dananjaya, t.th., 27). Kemudahan yang diberikan oleh teknologi tesebut hanyalah sebahagian daripada proses pengajaran dan pembelajaran di sekolah, sebagaimana ia menjadi sebahagian 
daripada pengalaman pembelajaran di luar sekolah. Jika mengacu kepada konsep total quality management disebutkan bahwa persekolahan haarus memperhatikan apa yang diinginkan dan yang dibutuhkan oleh pelanggan atau pengguna jasa pendidikan. Tuntutan masyarakat sebagai penggunna jasa pendidikan persekolahan dipengaruhi oleh perlunya kepentingan pengguna jasa tersebut disalurkan sesuai dengan prinsip ekonomi. Bagaimanapun pendidikan adalah jasa dan dianggap sebagai penjual jasa yang setiap saat harus melakukan inovasi dalam penyelenggaraan pendidikannya (Batubara 2004, 84-85).

Pilihan penting lainnya dalam memahami realitas sosial adalah apa yang berlangsung dalam dunia kita, pendidikan universitas lazim melatih para mahasiswa membaca buku teks, kemudian mengaitkannya dengan konteks yang terjadi terhadap perubahan sosial. Ini salah satu bentuk kritikan Fiere dimana nilai pendidikan tidak dapat dipraktekkan di luar lingkunagan pendidikan siswa, dan tidak mampu menjawab problem mereka. Bila persoalan dijawab dengan paradigma, maka yang harus dilakukan adalah menghadapi lembaga pendidikan dengan sasaran super canggih, karena sekolah adalah tempat dimana tujuan masyarakat tercipta, karenanya pelaku pendidik dan segenap yang ada didalamnya mengerti dengan perkembangan zaman, sepeti mampu mengoperasikan komputer, belanja lewat internet. Jelasnya pendidikan mensti mengenal perangkat-perangkat sosial dalam masyarakat agar mengerti bagaimana pola hidup masyarakat dimana mereka beradaptasi (Freire, Prihantoro, dan Fudiyartanto 2007, 195).

Dengan kemajuan teknologi informasi yang dulu tabu, sekarang terbalik menjadi transparan dengan format budaya baru tidak menutup kemungkinan akselerasi perubahan sosial akan membawa negara agraris menuju negara industri, sebagaimana dalam sejarahnya, peradaban dunia manusia adalah salah satu kehidupan dalam mengantarkan perubahan baru, bahwa pendidikan berproses semenjak manusia pertama diciptakan. Jadi pendidikan hendaknnya mampu memberikan selarasan antara perubahan sosial yang begitu cepat (Ilyas 2009, 44). 
Membangun kesadaran pentingnya sebuah transpomasi budaya/perubahan dalam membangun sebuah peradaban baru yang lebih matang. Oleh karena itu perubahan harus dilakukan dengan konsep yang matang dan siap atas konsekuensi disegala bidang. Guna memenuhi kesuksesan dimasa sekarang dan akan datang (llyas 2009, 31), sebagaimana yang dikatan John Dewey, "The School and Society" bahwa pengaruh industrialime pada pendidikan dan perlunya sekolah memangku fungsi sosial yang lebih besar. Lebih lanjut Dewey mengukuhkan komitmen terhadap tumbuh dan berkembanngnya demokrasi dalam bisang pendidikan yang bermuara pada pengakuan atas makna persamaan yang sebenarnya (Assegaf, dkk. 2007, 230).

Seperti permasalahan di atas dimasa sekarang, permasalahan yang paling mendominasi dunia pendidikan adalah kapitalisme pendidikan, kekayaan alam dan tenaga produksi dihisap oleh kapitalis baik asing maupun kolomerat suwasta sehingga untuk menentukan pendapatan pendidikan pemerintah tidak mampu membiayai pendidikan kita. Dengan masuknya sistem kapitalis tentu saja akan mmenunjukkan betapa mahalnya pendidikan itu, negara dipreteli perannya untuk melayani pendidikan bagi rakyat, dimana kapitalisme selalu ingin mengkomoditas, maka sekolah pun mulai dilihat sebagai lembaga yang dapat mendatangkan keuntungan jika dibisniskan. Tesis ini tak terbantahkan, Pertama, mahalnya biaya pendidikan di indonesia tercatat 75-80 persen dari tingkat SD sampai SMP putus sekolah dan 60 persen setingkat SMU mampu melanjutkan kebangku kuliah. Kedua, kapitaslime pendidikan membuat pendidikan eksklusif yang hanya kalangan kaya, hak-hak setiap orang untuk mendapatkan sekolah diingkari, sekolah yang pada akhirnya diisi oleh anak-anak berduit menunjukkan elitisme pendidikan (Soyomukti 2008, 157).

\section{Analisis Sturuktur Konflik}

Pendekatan sistem dikenal dalam banyak bidang sebagai alat merencanakan dan memecahkan masalah. Sebagaimana yang sudah di paparkan di atas, pendidikan dilihat diberbagai sudut pandang 
manapun masih dalam belenggu problem yang masih belum terselesaikan sampai saat ini. Dalam tulisan ini penulis mencoba menganalisis permasalahan yang sedang dihadapi dalam dunia pendidikan, dengan menggunakan struktur konflik kemudian kritikan dan pemetaan masalah dan bagaimanna hubungan pendidikan dengan realitas sisoal kita. Sebagaimana fungsi dan tujuan dari pendekatan ini supaya memberikan kesadaran dan kepekaan kita sebagai anak bangsa atas ketidak berdayaan dalam menyuarakan aspiransi pada pemerintah. Tidak berfungsinya suatu sistem yang di buat maka konflikpun terjadi di dalam sistem tersebut "masyarakat". Berkenaan hal tersebut dalam kebijakan dan sistem pendidikan yang semakin hari berubah-ubah yang berujung tidak terjangkaunnya biaya pendidikan dari kalangan bawah, maka konflikpun terjadi, walaupun dalam pendekatan ini tidak menggunakan media dalam memebrikan ktrikannya, dan dikatakan hanya sebagai wacana saja, setidaknya memberikan kita kesadaran atas apa yang terjadi dalam pendidikan kita saat ini, dengan tanpa memberikan kritikan para pemegang pendidikan (kaum elit kapitalis) perubahan tidak akan terjadi bahkan penindasan hak HAM akan terus berjalan.

Media yang diharapkan bisa memberikan dalam pendekatan ini dengan menggunakan sistem dan fungsi yang sudah ada, maksudnya dengan menggunakan media dalam pendekatan sttruktur fungsi kemudian media tersebut mengktirik dan memberikan solusi apa yang diharapkan dalam perubahan sosial masyarakat. Sebagaimana fenomena yang terjadi atas kritikan tersebut struktur fungsi pendidikan digunakan menggritisi kebijakan pendidikan tersebut, sebagai contoh aksi mahasiswa dalam merobohkan orde lama, dimana media yang bermain didalamnya melalui pendidikan yang pada ahirnya keberhasilan dan perubahan fungsi dan struktur pun terjadi.

Dengan demikian analisis sistem bagaimana menganalisis masalah-masalah yang konpleks dan yang bertujuan menentukan apa yang harus dilakukan dan upaya mencapai tujuan yang efektif, mengkritisi sistem yang sebelumnya hingga merubahnya jika itu 
diperlukan dan harus dilakukan untuk kepentingan sistem tersebut yang berimplikasi pada berjalannya pendidikan yang dinginkan oleh perubahan sosial (Soenarwan 2001, 205). Kebijakan pemerintah kekuasaan otonomi, dalam kebijakan tersebut terlihat permasalahan yang muncul kasus pilkada dan pembentukan lembaga pendidikan yang berkerjasama dengan perusahaan-perusahaan untuk menunjang mutu pendidikan lembaga pendidikan itu, namun pada akhirnya berujung pada biaya pendidikan dan uang.

\section{Kesimpulan}

Realitas pendidikan ditengah-tengah masyarakat masih dalam belenggu kebijakan dan penguasaan tangan kekuasaan, elit politik. Sebagai sistem kapitalis sebagai warna, perubahan kebijakan yang dibuat masih tidak bisa menjawab persoalan sosial. Terbentuknya dualisme kebijakan yang dibuat pemerintah masih membentuk struktur kelas dan pendidikan semakin mahal ditiap daerah. sebagai contoh solusi desentralisasi yang ditetapkan sisdiknas dengan tujuan penyetaraan mutu, kesempatan mendapatkan pendidikan yang layak, dan mudahnya mengakses pendidikan. Namun apa yang terjadi biaya pendidikan semakin tidak terjangkau dikalangan masyarakat menengah kebawah.

Otonomi daerah memberikan para mapia pendidikan bermain dibawah, sebut saja ketika Pilkada (Bupati dan Gubernur), kalu menang dari pemilihan tersebut orang yang diusung, akan ada balik jasa sesuai dengan kesepakatan mereka sebelumnya. Peluang ini di manfaatkan oleh para mafia pendidikan, dengan menawarkan para pelaksana pendidikan dan bahkan calon Bupati dan Gubernur tersebut menjanjikan kepada orang yang mendukungnya. Otonomi tersebut masih memberikan penindasan terhadap masyarakat kecil, terutama pada lembaga swasta yang hanya mengandalkan biaya dari siswa, akan jauh tenggelam tertinggal dan bahkan tidak dilirik oleh masyarakat dan pemerintah otonom. 


\section{Daftar Pustaka}

Abraha, Kamsul. 2004. Integrasi Sains- Islam Mempertemukan Epistemologi Islam dan Sains). Yogyakarta: Suka Press.

Arif, Mahmud. 2008. Pendidikan Islam Transpormatif. Yogyakarta: LKiS.

Asmani, Jamal Ma'mur. 2011. Tips Efektif Pemanfaatan Teknologi Informasi dan Komunikasi dalam Dunia Pendidikan. Yogyakarta: Diva Press.

Assegaf, Abd. Rachman. 2005. Politik Pendidikan Nasional: Pergeseran

Kebijakan Pendidikan Agama Islam dari Pro-Prooklamasi ke

Reppormasi. Yogyakarta: Kurnia Kalam.

Assegaf, dkk., Abd. Rachman. 2007. Pendidikan Islam di Indonesia. Yogyakarta: Suka Press.

Awignyo, Agus. 2008. Pendidikan Tinggi dan Goncangan Perubahan. Yogyakarta: Pustaka Pelajar.

Batubara, H. Muhyi. 2004. Sosiologi Pendidikan. Jakarta: Ciputat Press.

Dwiningrum, Siti Irene Astuti. 2011. Desentralisai dan Partisipasi

Masyarakat dalam Pendidikan. Yogyakarta: Pustaka Pelajar.

Freire, Paul, Agung Prihantoro, dan Fuad Arif Fudiyartanto. 2007.

Politik Pendidikan, Kebudyaan, Kekuasaan, dan Pembebasan. Yogyakarta: Pustaka Pelajar.

Ilyas, Hamim. 2009. Islam dan Trasnpormasi Budaya, Mewujudkan Perubahan Menuju Masyarakat Progresif. Yogyakarta: Legung Pustaka.

Isjoni. 2010. Dari Subtansi Ke Praksis: Pokok-pokok Pikiran Meningkatkan Kualitas Pendidikan. Yogyakarta: Pustaka Pelajar. Jalam, Faisal, ed. 2001. Reformasi Pendidikan dalam Konteks Otonomi Daerah. Yogyakarta: Adicita Karya Nusa.

Kurniawan, Syamsul. 2009. Pendidikan Dimata Soekarno, Modernisasi Pendidikan Islam dalam Pemikiran Soekarno. Yogyakarta: ArRuzz Media.

Mastuhu. 2004. Menata Ulang Sistem Pendidikan Nasional dalam Abad 21. Yogyakarta: Insania Press. 
Miarso, Yusuf Hadi. 2004. Menyemai Benih Teknologi Pendidikan. Jakarta: Kencana.

Mu'arif. 2008. Liberalisasi Pendidikan, Menggadaikan Kecerdasan Kehidupan Bangsa. Yogyakarta: Pinus.

Mulkhan, dkk., Abdul Munir. 1998. Rekontruksi Pendidikan dan Tradisi Pesantren Religiusitas Iptek. Yogyakarta: Pustaka Pelajar.

Rahardjo, Satjipto. 2009. Pendidikan Hukum sebagai Pendidikan Manusia Kaitannya dengan Proses Hukum dan Pembangunan Hukum Nasional. Yogyakarta: Genta Publishing.

Rembangy, Mustofa. 2010. Pendidikan Transformatif Pergulatan Kritis Merumuskan Pendidikan di Tengah Pusaran Arus Globalisasi. Yogyakarta: Teras.

Sanaky, Hujair AH. 2009. Media Pembelajaran. Yogyakarta: Insania Press.

Santoso, dkk., Listiyono. 2010. Seri Pemikiran Tokoh Epistemologi Kiri, kajian Revolusioner. Jakarta: Ar-Ruzz Media.

Soenarwan. 2001. Pendekatan Sistem dalam Pendidikan. Surakarta: Sebelas Maret University Press.

Soyomukti, Nurani. 2008. Metode Pendidikan Marxism Sosialis: antara Teori dan Praktik. Yogyakarta: Ar-Ruzz Media.

Tilaar, H.A.R., dan Riat Nugroho. 2009. Kebijakan Pendidikan Pengantar untuk Memahami Kebijakan Pendidikan dan Kebijakan Pendidikan sebagai Kebijakan Publik. Yogyakarta: Pustaka Pelajar. 